\title{
The Theory and Empirics of Financial Development in the East Asian Bond Markets
}

\author{
Thomas Kemetmüller
}

\begin{abstract}
The Asian financial crisis marked a turning point in financial development in East Asia that brought the development of bond markets within the focus of policy-makers. This paper tracks the benefits of an advanced bond market, the current state of the East Asian corporate and government bond markets and their rapid evolution since the Asian crisis. Subsequently, a multivariate model is used to determine the endogenous economic and institutional factors that drove growth in the region's bond markets. The following findings may be noted: (1) growth in the government bond market was driven by the monetary sterilisation efforts of East Asian central banks in order to cope with excessive liquidity, (2) the government bond market may crowd out the corporate bond market, and (3) the corporate bond market grew particularly strongly during the global financial crisis.
\end{abstract}

Keywords: East Asia, bond market, financial development, monetary sterilisation, econometric analysis

Prae Kemetmüller, Thomas. "The Theory and Empirics of Financial Development in the East Asian Bond Markets.” In Vienna Journal of East Asian Studies, Volume 5, eds. Rudiger Frank, Ina Hein, Lukas Pokorny and Agnes Schick-Chen. Vienna: Praesens Verlag, 2014, pp. 45-76. https://doi.org/10.2478/vjeas-2014-0003 


\section{Introduction}

The Asian financial crisis (1997-1998) marked a decisive turning point in the financial development of East Asia. It sparked discussions about crony capitalism, governance, short-term capital inflows and over-reliance on the banking system. It also brought the fact that most of East Asia was missing a bond market into focus, as bond markets perform diverse roles in an economy. Except for Japan, the region's corporate and government bond markets were virtually non-existent. The crisis revealed the vulnerability of having to rely on the banking system as the sole form of finance, and encouraged discussion among regional policy-makers of how to develop fixed income markets in the region. Since then the region's bond markets have grown tremendously. In the last decade they have more than quadrupled in size and are now able to perform an important role in the East Asian economy.

This paper tracks the debate and the actual development of the East Asian credit markets over the last 15 years. It reviews the potentials of developing and integrating bond markets, gives an overview of the current state of the market and uses panel data to determine the factors contributing empirically to market growth. From a bond market's point of view, two things in particular mark East Asia as a region: the Asian financial crisis as the major common event, and the financial cooperation emerging from the crisis. The regional initiatives that aim to develop bond markets also determine the choice of economies dealt with in this paper. China, Hong Kong, Indonesia, Japan, Korea, Malaysia, the Philippines, Singapore, Thailand and Vietnam are part of two regional projects, the Asian Bond Funds and the Asian Bond Market Initiative.

The paper is structured as follows: the next, second section takes a brief look at the current state of the East Asian bond markets and their growth since the Asian financial crisis. The third section gives an overview on the potential benefits of bond market development and integration. The fourth section reviews macroeconomic and institutional determinants of bond market growth, while the fifth and sixth sections use a multivariate model to estimate the determinants for the East Asian bond markets.

\section{The state of the market}

The two most basic indicators for the development level of a financial market are its size and its liquidity. The overall size of the market is usually measured in the total nominal amount of bonds outstanding. As the size of economies varies greatly, it can be misleading to compare solely nominal amounts of outstanding bonds. Instead, the ratio of outstanding bonds to economic activity (as measured in GDP) makes markets comparable. The absolute size of the bond market may nevertheless 
be relevant: Eichengreen and Luengnaruemitchai (2006: 44) suggest that small countries find it harder to establish bond markets as they lack a minimum efficient scale.

In terms of size, the East Asian bond markets developed rapidly after the Asian financial crisis. While 15 years ago in every country except Japan government debt was solely financed through debt denominated in a foreign currency or through the banking system, the local currency government bond market has developed rapidly since then: from 1998 to 2011 the market grew by 500 percent (AsianBondsOnline 2012). Although the government bond market was the primary driving source of overall bond market growth, the corporate bond market developed remarkably as well. Before the Asian crisis virtually no corporate debt was issued in all East Asian countries, except in Japan. Since then the volume of corporate bonds outstanding has grown by 255 percent. Despite this apparent rapid growth throughout the region, the state of development remains heterogeneous.

Japan's government bond market is one of the biggest and most mature debt markets in the world. The Korean, Malaysian and Singapore government debt markets form one of the most advanced markets, while the other markets are still developing rapidly. The only market actually shrinking in size is the Indonesian government bond market. While the regional government bond market grew rapidly, the corporate bond market grew more slowly than the region's GDP. The ratio of outstanding corporate bonds to GDP declined from 21.4 percent in 2000 to 17.6 percent in 2010. While most markets grew, the Chinese market stands out as it accounted for only 0.3 percent of GDP in 2000, but grew to over 10 percent in 2010 . The Japanese market actually shrank over the last decade, as firms are still in the process of deleveraging (AsianBondsOnline 2012).

In contrast to the size of a market, liquidity is a very illusive concept, but an important indicator of a market's efficiency. The depth, breadth, resilience, tightness and immediacy of a financial market are related to the market's liquidity (Baker 1996 ; Sarr and Lybek 2002). In essence a liquid market allows investors to sell an asset immediately without adversely affecting its price. Insufficient liquidity increases transaction costs and decreases the information content of price signals. Volume-based indicators, such as the turnover ratio (the ratio of bonds traded to bonds outstanding), and transaction cost-based indicators such as the spread between the seller's asking and the buyer's bid price (the bid-ask spread) are ways to measure the liquidity of a market.

Liquidity has improved throughout the whole region, but as with size, the region remains heterogeneous. Small markets as the Vietnamese and Indonesian government bond markets still have high bid-ask spreads. Similarly, these markets also have large bid-ask spreads in the corporate bond market. The Chinese, Japanese,

1 Cited in Alexandros et al. (2011: 4). 
Korean and Malaysian markets form the most liquid corporate bond markets. But the lack of liquidity is still a pressing issue in the whole region. Liquidity is exclusively limited to the primary market, as a secondary market virtually does not exist. A major reason for this is the absence of a diverse and active investor base in the region's markets, which are dominated by banks and pension and insurance funds that hold securities until maturity (ADB 2011; AsianBondsOnline 2011; AsianBondsOnline 2012).

Figure 1 Total outstanding LCY bonds in East Asia

\section{Total Outstanding LCY Bonds in East Asia (excluding Japan, billion US \$)}

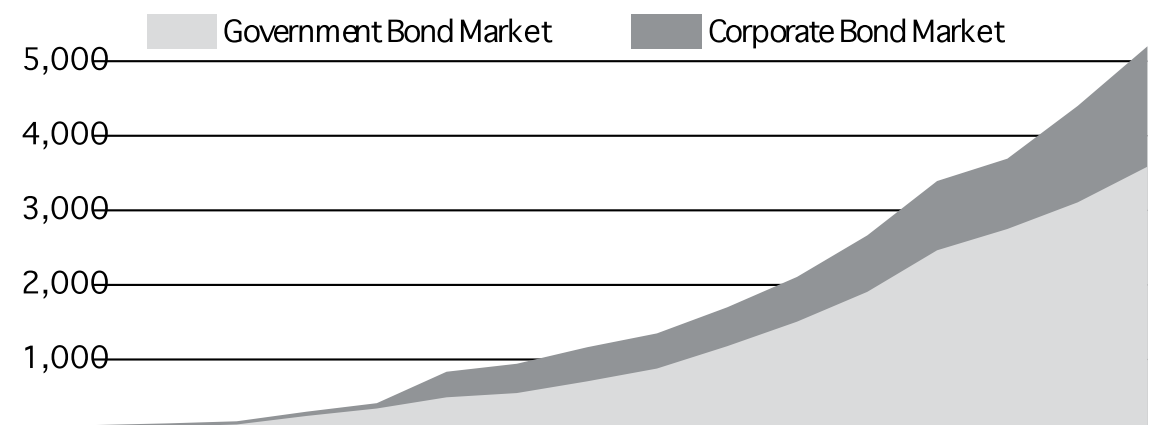

199519961997199819992000200120022003200420052006200720082009201 Source:AsiarBondsOnline

\section{Potentials of a developed bond market}

The Asian financial crisis marked the decisive point in the academic discussion of why the region should aim to develop its bond markets, as it provides a substantial example of why a bond market might have been able to prevent the crisis. Despite several illustrative narratives, the academic literature on the general role of the bond market in the economy is scarce. Most literature focuses on the benefits of other capital markets such as the stock market or bank debt. But nevertheless there seems to be several clear potential benefits of a developed bond market.

\section{Government bond market}

While corporations have to take the state and regulation of the market as given, the government acts as both an issuer and an investor in bonds, while concurrently regulating the market and enforcing the regulatory framework. Governments have several ways to finance their government debt. Finance through the government bond market at undistorted market rates is supposed to have the least disturbing 
effect on financial markets and is consequently regarded as the most efficient means of government finance, Fry (1997) identifies three additional ways, which all impose additional costs and disruptive effects on the market. A government may (1) monetise its debt by borrowing directly from the central bank, a move that may cause inflation, (2) financially repress national actors by forcing them to hold more government securities than they would hold voluntarily and thereby demand lower interest rates, and (3) borrow in a foreign currency. By being able to shape the market, policy-makers in countries with weakly developed institutions may be tempted to influence the market so as to be able to finance government debt more easily. Borrowing through debt markets at market rates is regarded as the method causing least disruption to markets to finance government debt (Fry 1997).

With deep and liquid government bond markets, central banks are also able to conduct monetary policy more easily and without forcing additional costs on actors in the financial market. Without sufficiently developed government bond markets, central banks have to rely on non-market instruments such as adjusting reserve requirements in order to steer liquidity and conduct monetary policy. While such policies are equally effective, they are costly because they force economic actors to adjust their balance sheets. With liquid and deep government bond markets, central banks can rely on open market operations to conduct monetary policy (Nyawata 2012).

In order to reduce medium- and long-term liquidity in the financial markets by open market operations, monetary authorities may sell securities (usually government bonds) or issue their own central bank bills to reduce cash in circulation (Agénor and Montiel 2008: 226-227). While central banks can act independently when issuing bills on their own, they may thereby possibly fragment the government bond market. In turn, when co-ordinating with the government before monetary intervention, they can help to 'lump' and create a market (McCauley and Remolona 2000: 55).

Following the Asian financial crisis, East Asian countries started using the bond market widely to conduct monetary policy. A large part of East Asia's government bond market growth can be attributed to these monetary sterilisation efforts of central banks. Since the crisis, the East Asian countries have built up substantial foreign exchange reserves. This practice has mitigated the appreciation of the East Asian currencies, but has also led to a rise in liquidity in the financial markets. By 2001, all monetary authorities in the region had been required to deal with superfluous liquidity (Löffler et al. 2012: 8). Except for China, central banks in the region primarily resorted to open market operations in order to decrease liquidity: either governments issued government bonds and deposited the proceeds at the central bank, or monetary authorities issued central bank bills directly. Both approaches led to a rapid rise in the government bond market. China used a combination of open market operations and reserve requirements in the banking sector in order to cope 
with excess liquidity (Greenwood 2008: 209). It seems that the sterilisation efforts of central banks were a major driving source in government bond market growth. This hypothesis will be tested empirically in the next section. But the large supply of government bonds could also have negative effects on the economy. Mohanty and Turner (2006: 49) mention negative externalities and the possibility of a crowdingout in the private sector. ${ }^{2}$ Nyawata (2012) notes that sterilisation bonds may not have the same positive externalities on the corporate bond market as ordinary government debt. And by having to pay the interest on the issued bonds, central banks face the risk of balance sheet losses. From 2004 to 2007, the Bank of Korea 'accumulated interest rate losses of roughly 0.5 percent' and losses due to revaluation of 1.7 percent of GDP. From 2000 to 2010 , five central banks in the region had to face balance sheet losses (Löffler et al. 2012: 16).

Established government bond markets have the major benefit of providing information to investors through a yield curve. A yield curve consists of yields (interest) on a security with different maturities. Because government bonds are usually very homogeneous and often considered to be one of the safest assets in an economy, a government-benchmark yield curve may provide valuable information on expectations of interest and economic activity to investors (ECB 2012). For example, the US yield curve predicted every recession after World War II with the exception of a slowdown in the 1960s. But the reliability of the yield curve as a predictor for economic activity was challenged recently, and empirical evidence for emerging economies remains scarce, in part because they have only recently managed to establish domestic securities markets (Mehl 2006). Governments can actively support the establishment of a yield curve by concentrating the issuance of government bonds on several key maturities ${ }^{3}$ that are spread over the maturity spectrum (World Bank 2001: 13). By establishing a yield curve in the government bond market, the government may provide positive externalities on the corporate bond market, as investors can compare and price yields on corporate debt more easily.

East Asian governments issued bonds over various maturities and managed to establish yield curves in every country. But low liquidity remains an issue and the yield curves of some countries experienced the obscurity of jumps over several maturities. They should even out with sufficient liquidity and provide reliable information to investors. But the benefits of a yield curve seem to be diminishing with stable exchange rates against the dollar. In South Korea, Malaysia, the Philippines and Singapore, the curve has at least at one horizon (short-, medium- or longterm) some predictive content on growth or inflation according to Mehl (2006). As markets and infrastructure have grown since his study, it can be expected that the

2 Crowding-out describes a situation in which increased government borrowing decreases the amount of private borrowing, causing overall little or even negative change in total borrowing.

3 The maturity of a bond is the period until the nominal amount is being repaid by the issuer. 
East Asian yield curves have an even more significant beneficial effect today. Government bond markets may also have additional spill-over effects on the corporate bond market, because the established regulatory framework and market infrastructure can make it easier for firms to issue bonds. In the following section, where the determining factors of bond market development are analysed empirically, the level of development of the government bond market will tested for any positive influence on the corporate bond market.

\section{Corporate bond market}

Like the banking sector or the equity market, the corporate bond market provides financial intermediation between different economic actors. The primary functions of financial markets are the mobilisation of savings, the management of risk, the facilitation of exchange and the obtainment and provision of information (Spratt 2009: 52). There is consensus in the economic debate that growth in financial markets has a positive effect on economic growth (Spratt 2009), although the theoretical debate that started as early as 1911 with Schumpeter (1993) has not finally been settled yet. Other economic theories see financial intermediation as neutral (Lucas 1988) or with a negative effect on economic growth (Fink et al. 2003: 6-7). Comprehensive empirical research by Levine (1997) attested that financial markets in general have a positive effect on growth. Similar results can be found for the Asian and East Asian regions: Habibullah and Eng (2006) and Fase and Abma (2003) found a strong link between the financial sector and real economy growth prior to the Asian financial crisis. ${ }^{4}$ Estrada et al. (2010) also found a positive effect for financial intermediation and sophistication on per capita growth and a particularly higher effect on Asian economies. But this effect is diminishing over the course of economic convergence (Fung 2009), as financial markets must make the transition from primarily mobilising savings to managing risk and efficiently distributing capital (Estrada et al. 2010).

Economic theory on financial intermediation has mostly taken the form of analysing the role of bank debt and equity in corporate finance. Theory on the intermediating role of the corporate bond market is scarce. Bolton and Freixas (2000) created a theoretical financial markets model incorporating equity, bond- and bank debt under asymmetric information that demonstrates the decision of companies when choosing an optimal capital structure. The optimal capital structure is primarily affected by the firm's riskiness. Risky firms, such as start-ups, are only able to fund themselves through equity and are not able to obtain other funds. Firms that are less risky, but safer, finance themselves through bank debt as it provides a

4 Estrada et al. (2010: 43) notes though: 'It would take a leap of faith to view a banking boom characterized by reckless lending and rapidly deteriorating quality of investment as financial development'. 
flexible and negotiable form of finance, and banks have special expertise in assessing risk adequately. The safest firms use the corporate bond market as a source of cheap funds. With an established corporate bond market, safe firms are thus able to circumvent the intermediation costs of banks and finance in the capital market directly. Additionally banks may also try to free their balance sheet from the safest assets by securitising them and use the freed-up capital where returns are higher (Bolton and Freixas 2000: 338-339). An economy without a corporate bond market will consequently face an inefficient capital allocation, as safe firms would still have to rely on banks for finance. This is more costly for both: firms face higher costs of capital, as banks charge a spread on their own costs of capital. Banks in turn cannot use their capital efficiently and have to keep safe, low-yield debt on their balance sheets. The bond market also makes it easier to finance huge long-term projects, such as infrastructure investments. The East Asian banking-based financial system had already reached its limits prior to the Asian financial crisis, as large companies had problems financing large projects without giving partial ownership to banks, a problem that could have been mitigated by an established bond market (Eichengreen and Luengnaruemitchai 2006: 40).

Comprehensive empirical research on the influence of bond markets on economic growth over a large sample of countries has not yet been published, primarily because of a lack of data (Barth et al. 2006: 12). But existing literature overall finds a positive link between bond market growth and economic growth. Fink et al. (2003) find a bi-directional causality between growth in the real economy and in the bond market in Japan and evidence for a positive impact on economic growth in many other countries. More recent empirical research into emerging markets showed a particularly high impact of bond market development on economic growth, compared with other forms of finance (Fink et al. 2009). In contrast, Estrada et al. (2010) find that the structure of finance (ratio of equity, bank credit and bond debt) is not as important as financial deepening as a whole. Despite these diverse results and only little empirical literature on the effects of bond market development, it can be expected that growth in the bond markets exerts a positive causal influence on economic growth. In East Asia, the region's capital structure has essentially remained unchanged, despite the growth in the corporate bond market. Relative to other sources of finance, bond market growth has remained modest: bank credit has grown significantly faster than economic activity in most East Asian countries. Bank credit thus remains the most important source of finance in the region.

The desire to develop bond markets in the East Asian region was heavily driven by the experiences of the Asian financial crisis. It showed that the region lacked a bond market to substitute for the banking sector as a financial intermediary and as a way of investing savings locally. Prior to the crisis, strong economic growth was amplified by large capital inflows and exaggerated by the fact that Asian savers had only few opportunities to invest their savings outside of the stock market. Instead, 
they invested mainly in dollar-denominated foreign assets, which in turn were 'recycled' back into the region in the form of short-term investments. Banks used these short-term funds in foreign currency to finance long-term loans in local currency. As foreign investments stopped, the region was suddenly exposed to this socalled 'double mismatch' in both maturity and currency (Ismail and Sivalingam 2006: 28). As banks had to reduce their lending, the crisis fed from the financial sector into the 'real' economy.

Bond markets could have mitigated the risk of a double mismatch and could have possibly played the role of a financial intermediary at a time when the banking sector had to cut back lending. Alan Greenspan, the chairman of the Federal Reserve Bank during the Asian financial crisis, coined the term of the missing 'spare tire': East Asia's financial system was relying on banking as the primary form of financial intermediation, and when the channel broke down, the region lacked a back-up source of financial intermediation. 'The lack of a spare tire is of no concern if you do not get a flat. East Asia had no spare tires' (Greenspan 1999). The bond market is seen as the primary spare tire that could have impeded the situation of a double mismatch, as it could have allowed governments and corporations to finance inconditions of adequate maturity and currency. In 1998, Donald Tsang (Zēng Yīnquán 曾 蔭權), the financial secretary of Hong Kong, cited the lack of a robust and efficient Asian bond market as one of the main reasons for the Asian financial crisis: a bond market could have provided a channel through which Asian investors would have been able to invest their savings within Asia, instead of those savings being recycled back in the form of foreign short-term funds (Park and Wyplosz 2010: 76). Since then, a functioning and efficient bond market has been seen as a way to foster financial stability and prevent another such event as the crisis of 1997-1998. The development of such a market became a major goal of policy-makers in the whole East Asian region.

Whether or not the East Asian corporate bond market would be able to play the role of a 'spare tire' remained doubtful for the first decade after the Asian financial crisis. As mentioned above, there remains plenty of room for development in the corporate bond markets. Most of all, liquidity is low and almost limited to the primary market. The global financial crisis, which started in 2008, was the first crucial test for the region's debt markets. The channels of international banking and especially international trade transmitted the effects of the crisis into the region. Stable, domestically induced growth dampened these effects, and Asian countries were quickly able to bounce back to high economic growth. That crisis can by no means be compared to the events of 1997-1998 (Emmers and Ravenhill 2010: 1-3). But global deleveraging and the sudden reversal of capital flows have also put the East Asian financial system under serious stress. In this situation the East Asian corporate bond market could have played the role of a spare tire. But at first it was not able to: at the height of the financial crisis, with the collapse of Lehman, the 
region's debt markets were illiquid as trading ceased. But soon they started to pick up again and continue to be a source of finance (Felman et al. 2011; Chan et al. 2012).

Figure 2 Emerging market corporate bond issuance

Emerging Market Corporate Bond Issuare

(billions US \$)

m Asia $\square$ Latin America $\square$ Developing Europe $\square$ Africa \&Middle East

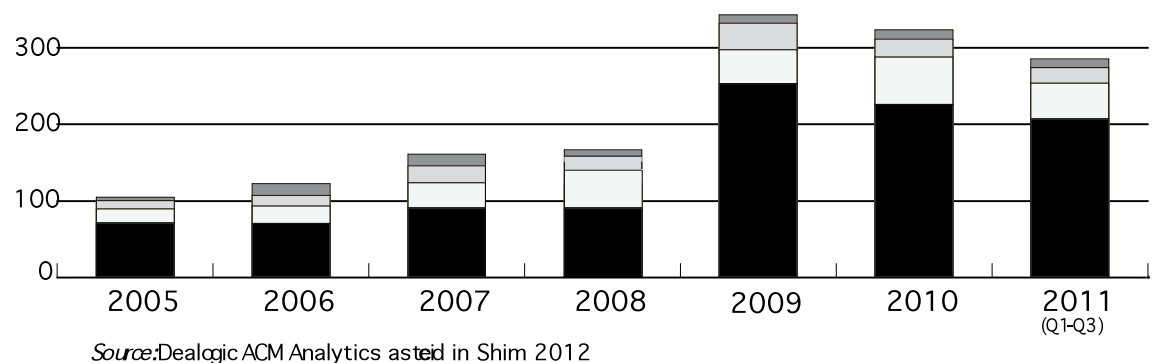

With 2009 the corporate bond markets suddenly started to grow rapidly. Figure 2 shows the issuance of corporate debt in several Asian countries. Felman et al. (2011) identify two major reasons for this sudden development: East Asian banks followed their Western counterparts and started to deleverage; firms started to substitute for this missing bank credit by issuing corporate debt instead. The market base grew rapidly: from 2007 to 2008 the number of issuers grew by roughly 50 percent. Simultaneously overseas demand for East Asian securities grew rapidly. Starting in 2009, the region faced large inflows of capital (Shim 2012: 8). The major factors driving these capital flows were abundant international liquidity, improved macrofundamentals, and Asia as the global engine of growth (Felman et al. 2011), as well as widened international interest rate differentials (Turner 2012).

Despite these positive developments, the most pressing issues, such as low liquidity and the virtually non-existing secondary market, continue to be an issue. And even though the East Asian corporate bond market played the role of a 'spare tire' during the global financial crisis, it remains doubtful whether the market would be able to play this role if the crisis were to originate from the region itself. While empirically determining the factors of bond market growth in East Asia, the hypothesis that the period of the global financial crisis also affected bond market growth will be tested.

The financial integration of bond markets also can have several positive effects on the efficiency of bond markets. It increases liquidity through a broader investor base and increased market participation, which improves the efficiency of markets and the information content of price signals (Borensztein and Loungani 2011: 54) and decreases transaction costs (Peiris 2010). Foreign investors are also more likely 
to trade actively than many investors in less-developed markets who are building their portfolio and follow buy-and-hold strategies. Integration and the participation of foreign investors can thus increase the liquidity in secondary markets significantly (Peiris 2010: 3, 7). Countries with small domestic bond markets would be able to issue larger amounts of bond debt, as foreign participation diversifies the investor base and increases the potential demand for bonds (Black and Munro 2010: 106). Despite the positive effects of financial integration and the participation of foreign investors, this could also make the financial system more fragile. As the Asian countries experienced during the Asian financial crisis, foreign investors' capital flows may be pro-cyclical, because investors want to invest heavily in growing markets but might be reluctant to invest during 'bad' times. Foreign capital, especially short-term portfolio inflows, may also increase market volatility as investors are shown to be susceptible to herding, rapid movements and contagion (Agénor and Montiel 2008: 491). But empirical research by Peiris (2010) does not find that increased foreign participation in the local currency bond markets led to increased volatility in bond-yields. ${ }^{5}$ Agénor and Montiel (2008: 493) also find that foreign banks may have uneven lending patterns that could possibly have a destabilising effect. The argument can similarly be adapted for the corporate bond market: foreign investors may invest only a little in low-rated bonds and instead focus on the highly rated part of the market in order to avoid risk. Such an uneven distribution in the debt capital market could decrease the efficiency of the financial system and may have adverse effects on output and growth. Financial systems may especially be more fragile and susceptible to shocks and crises with only weakly developed institutions. In particular, the problem of asymmetric information between foreign investors and domestic actors can lead to a misallocation of capital, which may be a potential source of financial instability. This emphasises the necessity of establishing solid regulatory practices alongside the liberalising of the capital account (Agénor and Montiel 2008: 490).

Financial integration in the East Asian bond markets seems weak at best. Financial openness in the region is very heterogeneous, with Hong Kong, Japan and Singapore being fully open to foreign investors, Thailand and China being far more closed, and the other countries lying between these extremes (Aizenman et al. 2008). While research on the East Asian equity markets has usually found some degree of financial integration ( $\mathrm{Yu}$ et al. 2007b), there is only limited evidence for integration in the bond markets. Co-integration models mostly find no integration (Calvi 2010) or only weak integration (Yu et al. 2007a; Johansson 2008). Borensztein and Loungani (2011) find that Asian investors have a higher home bias in their portfolio than the average global investor, and that they seem not to have an 'Asia-specific' prefer-

5 Though this findings show an increased volatility for Korea but diminishing volatility in Malaysia. 
ence for government debt, but instead invest globally. Government bond yields also seem to be more influenced by global than regional markets (Bae and Kim 2011).

\section{The determining factors of bond market growth}

As the Asian financial crisis was sparking the discussion of why Asia does not have bigger bond markets, Eichengreen and Luengnaruemitchai (2006) conducted a comprehensive empirical study on the determining factors of bond market development, in order to shed light on which institutional and macro-economic factors influence the state of development of these markets. Similar studies on general bond market development have been conducted by Dickie and Fan (2005), Burger and Warnock (2006), and most recently Bhattacharyay (2011). The following section reviews the literature on the most important endogenous determinants of bond market growth, while the succeeding section will examine them empirically for a dataset of the ten Asian countries.

\section{Macro-economic factors}

\section{Size of the economy}

The size of the economy may be an important factor, as small economies may lack a minimum effective scale that provides sufficient market participations and liquidity. Small markets may also be more volatile as single order and investors can have a larger market impact. Increased market volatility and low liquidity require investors to charge an additional yield premium that in turn can make the market even more unattractive. The size of the economy may thus be expected to be positively related to bond market development, especially in the early stages of the market (Eichengreen and Luengnaruemitchai 2006: 44-45).

\section{Developmental stage of the economy}

The stage of overall economic development (mostly measured in GDP per capita) is a proxy variable that encompasses several different explanations. Countries that are economically more highly developed are believed to have a more stable investment environment that encourages long-term finance and investment, less government involvement and manipulation, and overall better developed financial institutions, such as creditor rights, corporate governance and the rule of law. All these are positively associated with bond market development (Eichengreen and Luengnaruemitchai 2006: 46). 


\section{Exchange rate stability}

Stable exchange rates make the bond market more attractive to foreign investors and domestic corporations that rely on trade and less exposed to exchange rate shocks. A stable exchange rate is thus expected to have positive effects on bond market development (Eichengreen and Luengnaruemitchai 2006: 47-48).

\section{Inflation}

High inflation is associated with an unfriendly investment environment, as companies and investors face high uncertainty, and long-term finance may be discouraged. Bond markets may thus benefit from a low and stable inflation rate. Empirical research from Burger and Warnock (2006) finds this expected beneficial effect of a stable inflation rate on the establishment of bond markets.

\section{Interest rate spread}

A high interest rate ${ }^{6}$ spread is assumed to have a negative effect on bond market development because it makes long-term investments less attractive to investors as they perceive a high risk that the purchasing power of fixed long-term bonds may diminish in the future. Similarly, high levels of interest rate variability and an overall high interest rate also have a negative effect on bond market development as it makes it harder for companies to service their debt (Eichengreen and Luengnaruemitchai 2006: 47; Bhattacharyay 2011: 7).

\section{Large firms}

Dickie and Fan (2005) find that a large number of firms in the Global Fortune 500 list in an economy contributed positively to bond market development. They come to the conclusion that large firms may be able to issue on a 'name' and reputation basis and are less likely to fail than smaller enterprises.

\section{Pension system}

The pension system a country employs may also have an effect on the stage of bond market development. Defined-benefit pension schemes are often financed on a pay as you go basis, while defined-contribution schemes invest the payments. As the

6 The interest rate spread is the difference between the interest rate charged by banks for loans to the private sector and the interest rate paid for deposits. 
bond market is usually less risky and volatile and more oriented towards the long term than stocks, it is an attractive investment option for pension funds. Dickie and Fan (2005) find that countries with a defined-contribution scheme tend to have bigger corporate bond markets than countries with a defined-benefit scheme.

\section{Fiscal policy}

A government's fiscal policy is an obvious determinant of the government bond market size. Traditionally, government debt constitutes the largest part of the government debt market. As government debt is a major component there is an apparent positive effect of fiscal policy on the size of the government bond market. But the economic literature also explores the idea that government debt can raise interest rates and consequently may crowd out private debt. This would imply a possible negative effect of government bond debt on the corporate bond market. (Brunner and Meltzer 1972; McCauley and Remolona 2000; Eichengreen and Luengnaruemitchai 2006)

\section{Institutional factors}

\section{Origin of legal system}

La Porta et al. (1998) find that countries with a legal system in the common law tradition have stronger protection of investor rights than countries with a civil law tradition. Stronger investor rights foster the overall development of financial markets, and with weaker rights investors are more likely to invest in the banking system instead of the bond market. But Eichengreen and Luengnaruemitchai (2006) could not find sufficient empirical evidence to prove such a relationship in Asia.

\section{Bond and bank debt-complement or substitute?}

Eichengreen and Luengnaruemitchai (2006) were the first to point out a potential complementary relationship between the banking sector and the bond market, as they found empirically that countries with bigger banking systems also had larger bond markets. But research also suggests that strong interest groups play an important role in the development of the financial system and incumbents and rent-seekers can possibly slow down and even reverse this process (Rajan and Zingales 2003). Dickie and Fan (2005) tested this theory empirically for 34 different bond markets. They found that bond markets may compete with banks for profitable banking 
business and that strong concentrated banking institutions may thus try to impede the development of a corporate bond market.

A similar argument can be made with regard to the openness of an economy: increased openness makes it harder for interest groups and rent-seekers to persist as international competition makes them less powerful. Hence more open economies are expected also to have larger bond markets (Eichengreen and Luengnaruemitchai 2006: 45).

\section{Corporate governance}

Although corporate governance is primarily associated with stockholder rights, there are certain spill-over effects of good practice towards stock owners on bond holders, as both face better information with good corporate governance practices. Byun (2007) finds that Korean corporations with perceived better governance also face lower costs in the debt capital market. Ananchotikul and Eichengreen (2009) found that good corporate governance has a positive effect on the size of the corporate bond market, but not on the government bond market. The only two outliers in the Asian sample were Malaysia and the Philippines.

But research by Lin et al. (2012) comes to the different conclusion that firms that are primarily under family control try to avoid bank monitoring and thus prefer the dispersed monitoring of the bond market. Firms with weak corporate governance are thus more likely to issue debt in the bond market.

\section{Contract enforcement and rule of law}

As with good corporate governance practices, bond markets seem to benefit from a similar environment as the banking system. Both rigidly enforced creditor rights and a strong rule of law are suspected to benefit market-based financial systems, because they protect investors and provide certainty (Burger and Warnock 2006). Corruption may drive up the risk premium and in turn deter both investors and bond issuers. Economic freedom and civil liberty rights in turn are associated with increased competition, lowered yields and a more certain investment environment, which has a positive effect on bond market development. Empirical research supports these theses (Khalid and Rajaguru 2010: 7).

\section{Government commitment}

Dickie and Fan (2005) found that one of the most important contributing factors is the outspoken commitment of governments to support the development of the bond market. Governments are one of the main actors in the building of financial markets, 
as they can shape regulations, provide infrastructure and prevent situations in which the corporate bond market is held hostage by a few large established institutions. Malaysia and Korea have been actively supporting the development of their respective bond markets: Malaysia has created a dedicated fund to manage retirement savings and a corporation to securitise small loans, while Korea has provided government guarantees for large industrial conglomerates (the chaebols 재벌) (Dickie and Fan 2005: 5).

\section{Three hypotheses}

In reviewing the current state of the East Asian bond market, three hypotheses are proposed that will also be tested empirically in the multivariate regression:

- The first thesis proposes that East Asian monetary authorities' sterilisation efforts, by issuing central bank bills, have played a major role in driving growth in the government bond market.

- The second hypothesis suggests that the government bond market has positive externalities on the corporate bond market.

- The third hypothesis asserts that the East Asian corporate bond market was able to play the role of a spare tire during the global financial crisis, by substituting for receding bank debt.

\section{Method and data}

Most of the empirical literature reviewed chooses the factors of bond market growth either in developed markets or in a combination of developed and developing economies. Only Bhattacharyay (2011) conducted research specifically on the East Asian region. Dickie and Fan (2005), Eichengreen and Luengnaruemitchai (2006) and Ananchotikul and Eichengreen (2009) use East Asia as part of a bigger sample or as a sub-sample.

The dataset consists of panel data for the ten bond markets of China, Hong Kong, Indonesia, Japan, South Korea, Malaysia, the Philippines, Singapore, Thailand and Vietnam. The dataset was assembled from various sources, most notably IMF (2012), Kaufmann et al. (2010) and World Bank (2012). A detailed overview of the data used can be found in the appendix. The dataset ranges over the period 19952010 , but the availability of data is limited by several variables. This is a major impediment for many advanced statistical methods. Balanced panel data (when each variable is available in every cross-section) is available for the period between 2000 and 2010 for the dependent variables and between 2002 and 2009 for most independent variables. Continuous data are especially lacking for institutional variables 
in the period before 2002. Bhattacharyay (2011) was also limited by continuous data, but estimated a model with fewer coefficients. The major differences with Bhattacharyay's estimation are a different source for exchange rate variability, another definition of the openness indicator, and a different sample period, as Bhattacharyay's sample ranges from 1998 to 2008. The state of data availability means that several variables have had to be omitted. Fiscal policy, the number of large firms, the origin of the legal system and inflation have not been included. The origin of the legal system has been omitted, as Eichengreen and Luengnaruemitchai (2006) could not find sufficient evidence for the East Asian region and the variables used already included several dummy variables. Neither did Bhattacharyay (2011) include fiscal policy.

A GLS (Generalised Least Squares) estimator is used to estimate the regression, as the assumption of the OLS (Ordinary Least Squares) estimator that errors are independent and identically distributed easily becomes problematic when dealing with panel data. The GLS estimator deals with this problem by using the sample variance in order to estimate the coefficients. The GLS estimator is more consistent than the OLS estimator, but comes with the stronger assumption that no element of the regressors is correlated with any other element of the residuals (Wooldridge 2002: 49-57, 127-129, 143-162). All regressions are tested for heteroskedasticity (varying variance in different sub-samples), serial correlation and cross-sectional correlation and dealt with accordingly. While heteroskedasticity does not affect the consistency of the GLS estimator, accounting for it provides a more efficient estimation and corrected standard errors (Wooldrigdge 2002: 125-128). A likelihood-ratio test between the homoskedastic and heteroskedastic model is used to determine which model is to be used (Wiggins and Poi 2003). As with heteroskedasticity, standard errors in a model prone to serial correlation (correlated error terms) become biased and lose robustness (Drukker 2003). How to deal with serial correlation depends on the situation encountered, as the GLS estimator is theoretically capable of dealing with serial correlation on its own. But Beck and Katz (1995) find that the feasible GLS estimator can underestimate the variability of coefficients by up to 300 percent. A common way to deal with serial correlation is thus to include a lagged dependent variable. But such dynamic models may in the presence of high autocorrelation still underestimate the coefficients of the true underlying process (Keele and Kelly 2006). All models are tested for serial correlation by conducting a Wooldridge-test (Wooldridge 2002: 282-283). When serial correlation is encountered, a dynamic model (including a lagged dependent variable) is used. Given the long-term nature of most bonds, this can easily be justified, as only a fraction of bonds is maturing in any given year.

Panel data are especially susceptible to cross-sectional correlation (common shocks in different sub-samples). Under the assumption of a common shock that is uncorrelated with the regressors, the standard GLS estimator is not efficient (al- 
though consistent) and standard errors become biased. To test for cross-sectional correlation the Pesaran test will be used as in De Hoyos and Sarafidis (2006). The underlying source of such common shocks faced by the panel could be explained by the regional nature of the data.

The model specification is based upon Bhattacharyay (2011) and Eichengreen and Luengnaruemitchai (2006). Bhattacharyay (2011) used a model with macroeconomic variables, whereas Eichengreen and Luengnaruemitchai (2006) used additional institutional variables. As data availability and a small sample size are major constraints, the model is estimated in two steps to improve the robustness of the overall results and avoid the over-fitting of the regression. At first the macroeconomic and institutional variables are estimated separately and in a second step in a common model. Special attention is paid to changes in the significance level and sign of coefficients. Lastly the variables are added that test the three hypotheses proposed. This procedure is repeated for both the government and the corporate bond market separately. As the size of the Japanese government bond market is a massive outlier, not only within the region but in the whole world, a dummy variable for the Japanese sub-sample is added in the regressions of the government bond market.

\section{Results and discussion}

\section{Government bond market}

The results of the government bond market regressions can be found in Table 2 . Comparing the model specification, which uses solely macro-economic factors, to the results of Bhattacharyay (2011), we find several coefficients to be significant, while Bhattacharyay found only the interest rate spread and the size of the economy to be significant. The size of the economy becomes insignificant, though, as soon as the serial correlation correcting term is added. The reason for this could be a spurious regression between the size of the economy and the size of the government bond market, as both variables have a clear upward trend. Openness of the economy and the interest rate spread are both significant but have unexpected signs. The size of the banking system is significant with the expected sign. The coefficients in the regression seem more likely to be significant than the results of Bhattacharyay (2011).

In the second step, the institutional factors are estimated separately. As no major change in sign or significance of the coefficient happens when estimating the full model, a separate discussion is skipped. In the full model, GDP per capita as an indication of the economic development level becomes insignificant. Openness 
becomes slightly significant and switches from negative to the expected positive sign. Exchange rate stability becomes significant at the 5 percent confidence level, but with an unexpected negative sign. The variable denoting a government's rule of law suggests that governments with weaker rule of law have bigger government bond markets; while countries with a defined-contribution scheme seem to have smaller government bond markets. These findings are not explained by theory, but could be explained by the fact that governments that have only a weak rule of law might be also more likely to have loose financial policies. Similarly, governments with defined-contribution schemes might also have more stable public finances. The expected significant variables in the full model are openness, the interest rate spread, the size of the banking system, corruption, the regulatory framework, and outspoken government commitment.

In a last step a variable is added that indicates the monetary sterilisation efforts of central banks. The indicator is based on Aizenman and Glick (2009), who use the indicator to estimate a sterilisation coefficient for three East Asian countries. The variable is a ratio of net domestic credit assets and the reserve money.

$$
\text { Sterilisation }=\frac{\text { reserve } \text { money }- \text { foreign assets }}{\text { reserve money }}
$$

Aizenman and Glick (2009: 780) note that '[p] ositive values of net foreign reserve accumulation by the central bank correspond to foreign reserve inflows. Negative values of net domestic credit correspond to reductions in domestic assets held by the monetary authorities.' These reductions aim to decrease the liquidity in the domestic financial system. As was noted above, this is primarily achieved by issuing central bank bills. When using the variable in the regression we expect a negative sign, because monetary authorities reduce the net domestic credit assets (the numerator) when sterilising liquidity. This should in turn have a positive effect on the size of the government bond market. Put another way: the larger the amount of sterilised foreign assets in an economy, the lower the sterilisation coefficient. The indicator is negative for most of our sample, so to exert a positive influence the coefficient in the regression has to be negative. The sterilisation variable is added to all three model specifications. Table 3 shows the results. In all specifications the indicator is highly significant and with the expected negative sign. Thus the hypothesis that government bond market growth is heavily dependent on the monetary policy of East Asian monetary authorities cannot be rejected. 


\section{Corporate bond market}

For the corporate bond market, the macro-economic model is again used as a starting point. Bhattacharyay (2011) found the size of the economy, the stage of economic development, openness and the interest rate spread to be significant and with the expected signs. Exchange rate stability and the size of the banking sector had an unexpected negative sign. As can be seen in Table 4, we also find the size of the economy and the stage of economic development to be significant factors, but the size of the economy exerts a negative influence. This is also contrary to the findings of Eichengreen and Luengnaruemitchai (2006). Additionally we find the size of the banking system as well as exchange rate stability to be significant determinants with the expected sign.

In the next step, institutional factors are again estimated on their own. The rule of law, the regulatory framework and government commitment are found to have a significant positive influence. Bank concentration is weakly significant with an unexpected positive sign while the other coefficients are insignificant. When estimating the full model several changes in significance and signs occur. Significant results are GDP per capita, the size of the economy, the interest rate spread, exchange rate stability, corruption and government commitment. The size of the economy has an unexpected negative sign. The results of other determinants are not as clear, as the regression of the full model loses several degrees of freedom and may be prone to be over-fitted. The coefficients of the pension system, rule of law and openness are significant in all other specifications but the last. This indicates that the results lack robustness. Similarly to Bhattacharyay (2011), the interpretation of the results is thus also based on the regression, which does not include an autoregressive term, but the lack of robust results is being kept in mind.

The second hypothesis, which advances that the government bond market may have positive spill-over effects on the corporate bond market, is tested by adding the size of the government bond market to the regression. The results are shown in Table 5. In all three estimations the variable has a negative sign, and is highly significant in two. Other model specifications and estimators were also used, but the government bond market never had a positive effect on the size of the corporate bond market. Hence the hypothesis that the government bond market has positive externalities must be rejected. Instead it seems that there is a negative relationship, where a 1 percent increase in government debt decreases the size of the corporate bond market by 0.1 to 0.2 percent. This may indicate crowding-out effects from government debt. Further research is necessary to come to more robust conclusions, but the potential crowding-out of the private sector debt may also be a result of the rapid growth in government bonds in order to cope with excess liquidity (Mohanty and Turner 2006: 49). 
The last hypothesis, which suggests that the corporate bond market acted as a spare tire during the global financial crisis by substituting for bank credit, is tested by adding a dummy variable that takes the value of 1 for the period starting with 2008. The regression is conducted without adding an auto-regressive term, as it would lead to an underestimation of any shock variable, such as our dummy. Table 6 depicts the results. In all three estimations the variable has the expected positive sign and is significant at least at the 5 percent level. It seems that the market grew by about 2 to 2.4 percent specifically during the global financial crisis. The hypothesis can thus not be rejected, but the possible problems due to serial correlation have to be kept in mind. Table 1 gives an overview on the findings of the empirical analysis based on the multivariate model.

Table 1 Determinants of East Asian bond market growth

\begin{tabular}{|c|c|c|c|}
\hline & theory & government & corporate \\
\hline Bank credit & $+/-$ & + & - (ambig) \\
\hline Exchange rate stability & + & insig & + \\
\hline GDP per capita & + & insig & + \\
\hline Interest rate spread & - & + & - \\
\hline Openness & + & + & - (abig) \\
\hline Size of the economy & + & + & - \\
\hline Bank concentration & - & insig & insig \\
\hline Corruption & - & - & - \\
\hline DC pension scheme & + & - & $+($ ambig $)$ \\
\hline Government commitment & + & + & + \\
\hline Regulatory framework & + & + & insig (ambig) \\
\hline Rule of law & + & - & + (ambig) \\
\hline $\begin{array}{l}\text { Global financial crisis } \\
\text { Dummy }\end{array}$ & + & & + \\
\hline Government bond market & + & & - \\
\hline Sterilisation & + & + & \\
\hline
\end{tabular}

\section{Conclusion}

The East Asian bond markets have grown rapidly since the Asian financial crisis. While most markets were virtually non-existent after the crisis, they have developed both qualitatively and quantitatively. Nevertheless the region remains very diverse. Liquidity has improved substantially but remains low, with only a very small secondary market. Integration has been able to provide additional liquidity, but is low at best. All monetary authorities use the government bond market to some extent to 
conduct monetary policy and steer liquidity, and this factor has driven a substantial part of government bond market growth.

A multivariate model was used to determine the factors driving regional bond market growth, based on panel data from ten East Asian countries. Bank credit, exchange rate stability, economic development, the interest rate spread, openness, the size of the economy, corruption, the type of pension system, the regulatory framework, rule of law and the outspoken commitment of governments all affect the size of the East Asian bond markets. Additionally, three hypotheses were tested, from which it was concluded that monetary sterilisation of the region's central banks drove government bond growth; that the government bond market does not have positive spill-over effects on the corporate bond market, but is more likely to crowd out private investment by reducing the corporate bond market by about 0.1 to 0.2 percent for every percent of government debt; and that the East Asian corporate bond market was able to play the role of a spare tire during the global financial crisis and grew by about 2 to 2.4 percent particularly as a result of this event.

The fact that the region's bond markets were able to take on the role of a spare tire and substitute for bank lending shows that the markets have developed substantially during the last decade. But there is still room for improvement, especially in terms of liquidity and integration. The global financial crisis of 2008 is the first test the markets have passed, but whether they would be able to withstand a crisis originating from within the region remains to be seen. 


\section{APPENDIX - DATA}

$\begin{array}{ll}\text { Indicator } & \text { Source } \\ \text { Reserve money } & \text { IMF (2012) } \\ \begin{array}{ll}\text { Foreign assets } \\ \text { Sterilisation }\end{array} & \text { IMF (2012) } \\ \text { GFC dummy (2012) } \\ \text { GDP (PPP) } & \text { World Bank (2012) } \\ \text { GDP per capita (PPP) } & \text { World Bank (2012) } \\ \text { Interest rate spread } & \text { World Bank (2012) } \\ & \\ \text { Bank Credit } & \text { World Bank (2012) }\end{array}$

Openness

Corruption

Law

Regulatory

Exchange rate stability

Bank concentration

Government bond

Corporate bond

Pension DC

Government commitment

World Bank (2012)

\section{Description and comments}

national currency unit; monetary base used for IDN from 2001, JP, MY, PH and TH from 2009 instead national currency unit sterilization $=($ reserve money - foreign assets)/reserve money

one since 2008 current international \$, [NY.GDP.MKTP.PP.CD] current international \$, [NY.GDP.PCAP.PP.CD] lending rate minus deposit rate, [FR.INR.LNDP] domestic credit provided by the banking sector (percent of GDP) [FS.AST.DOMS.GD.ZS] imports + exports as share of GDP, [NE.IMP.GNFS.ZS + NE.EXP.GNFS.ZS]

Kaufmann et al. (2010) estimate of corruption estimate of rule of law estimate of regulatory framework exchange rate stability indicator assets of three largest banks as a share of assets of all commercial banks AsianBondsOnline (2012) percent of GDP; end of year values AsianBondsOnline (2012) percent of GDP; end of year values one for defined contribution scheme dummy, one for KR, MY and SGP 


\section{APPENDIX - REGRESSIONS}

Table 2 Determinants of the government bond market

\begin{tabular}{|c|c|c|c|}
\hline Variables & $\begin{array}{c}\text { (1) } \\
\text { gov_bond_gdp }\end{array}$ & $\begin{array}{c}\text { (2) } \\
\text { gov_bond_gdp }\end{array}$ & $\begin{array}{c}\text { (3) } \\
\text { gov_bond_gdp }\end{array}$ \\
\hline \multirow[t]{2}{*}{ gdp_ppp } & -0.0111 & & 1.995 \\
\hline & $(0.686)$ & & (1.542) \\
\hline \multirow[t]{2}{*}{ gdp_capita_ppp } & $11.89 * * *$ & & 4.955 \\
\hline & $(0.640)$ & & $(4.243)$ \\
\hline \multirow[t]{2}{*}{ openness } & $-0.0669 * * *$ & & $0.0514 * *$ \\
\hline & $(0.00568)$ & & $(0.0215)$ \\
\hline \multirow[t]{2}{*}{ i_spread } & $0.371 * * *$ & & $2.857 * * *$ \\
\hline & $(0.143)$ & & $(0.679)$ \\
\hline \multirow[t]{2}{*}{ bank_credit } & $0.196 * * *$ & & $0.168 * * *$ \\
\hline & $(0.0122)$ & & $(0.0336)$ \\
\hline \multirow[t]{2}{*}{ xr_stability } & -0.326 & & $-7.832 * *$ \\
\hline & $(0.983)$ & & $(3.492)$ \\
\hline \multirow[t]{2}{*}{ Japan } & $42.56 * * *$ & $121.5^{* * *}$ & $108.0 * * *$ \\
\hline & $(3.059)$ & $(24.85)$ & $(15.28)$ \\
\hline \multirow[t]{2}{*}{ corruption } & & $-6.138 * *$ & $-12.92 * * *$ \\
\hline & & $(3.046)$ & $(3.721)$ \\
\hline \multirow[t]{2}{*}{ law } & & $-11.44 * * *$ & $-26.65 * * *$ \\
\hline & & $(4.172)$ & $(4.761)$ \\
\hline \multirow[t]{2}{*}{ regulatory } & & $15.76^{* * *}$ & $22.96 * * *$ \\
\hline & & $(4.461)$ & $(5.277)$ \\
\hline \multirow[t]{2}{*}{ bank_concentration } & & -4.447 & 7.317 \\
\hline & & $(4.767)$ & $(5.901)$ \\
\hline \multirow[t]{2}{*}{ pension_dc } & & $-8.829 * *$ & $-13.01 * * *$ \\
\hline & & $(3.459)$ & $(2.304)$ \\
\hline \multirow[t]{2}{*}{ gov_commit } & & $27.62 * * *$ & $37.11 * * *$ \\
\hline & & $(3.393)$ & $(2.993)$ \\
\hline \multirow[t]{2}{*}{ Constant } & $-88.23 * * *$ & $27.38 * * *$ & $-110.0 * * *$ \\
\hline & $(18.56)$ & $(4.129)$ & $(34.45)$ \\
\hline Observations & 100 & 80 & 80 \\
\hline Panels (countries) & 10 & 10 & 10 \\
\hline
\end{tabular}

Standard errors in parentheses; *** $\mathrm{p}<0.01, * * \mathrm{p}<0.05, * \mathrm{p}<0.1$

(1) GLS estimator with panel-specific AR1 and cross-sectional dependent errors (2) \& (3) GLS estimator with panel-specific AR1 and heteroskedastic errors 
Table 3 Testing hypothesis 2: sterilisation driving the government bond market?

\begin{tabular}{|c|c|c|c|}
\hline Variables & $\begin{array}{c}\text { (1) } \\
\text { gov_bond_gdp }\end{array}$ & $\begin{array}{c}\text { (2) } \\
\text { gov_bond_gdp }\end{array}$ & $\begin{array}{c}\text { (3) } \\
\text { gov_bond_gdp }\end{array}$ \\
\hline gdp_ppp & $\begin{array}{c}11.02 * * * \\
(2.084)\end{array}$ & & $\begin{array}{c}4.388 * * * \\
(1.282)\end{array}$ \\
\hline gdp_capita_ppp & $\begin{array}{c}-12.81 * * * \\
(3.470)\end{array}$ & & $\begin{array}{l}-4.021 \\
(3.582)\end{array}$ \\
\hline openness & $\begin{array}{c}0.0545^{* * *} \\
(0.0150)\end{array}$ & & $\begin{array}{l}0.0279 * \\
(0.0151)\end{array}$ \\
\hline i_spread & $\begin{array}{c}0.262 \\
(0.210)\end{array}$ & & $\begin{array}{l}1.135^{*} \\
(0.600)\end{array}$ \\
\hline bank_credit & $\begin{array}{l}0.138 * * * \\
(0.0472)\end{array}$ & & $\begin{array}{l}0.111 * * * \\
(0.0304)\end{array}$ \\
\hline xr_stability & $\begin{array}{c}-3.813 * * \\
(1.655)\end{array}$ & & $\begin{array}{l}-3.214 \\
(3.138)\end{array}$ \\
\hline sterilization & $\begin{array}{c}-6.685 * * * \\
(0.577)\end{array}$ & $\begin{array}{c}-4.624 * * * \\
(0.665)\end{array}$ & $\begin{array}{c}-4.625 * * * \\
(0.713)\end{array}$ \\
\hline Japan & $\begin{array}{c}75.47 * * * \\
(7.667)\end{array}$ & $\begin{array}{c}129.9 * * * \\
(10.58)\end{array}$ & $\begin{array}{c}117.8 * * * \\
(12.03)\end{array}$ \\
\hline corruption & & $\begin{array}{c}-10.84 * * * \\
(2.518)\end{array}$ & $\begin{array}{c}-13.54 * * * \\
(3.074)\end{array}$ \\
\hline law & & $\begin{array}{c}-13.87 * * * \\
(2.708)\end{array}$ & $\begin{array}{c}-19.39 * * * \\
(3.553)\end{array}$ \\
\hline regulatory & & $\begin{array}{c}17.95 * * * \\
(3.201)\end{array}$ & $\begin{array}{c}25.41 * * * \\
(4.333)\end{array}$ \\
\hline bank_concentration & & $\begin{array}{l}-9.214 * * \\
(3.725)\end{array}$ & $\begin{array}{l}-3.413 \\
(5.306)\end{array}$ \\
\hline pension_dc & & $\begin{array}{c}-11.29 * * * \\
(2.412)\end{array}$ & $\begin{array}{c}-8.931 * * * \\
(2.137)\end{array}$ \\
\hline gov_commit & & $\begin{array}{c}15.09 * * * \\
(3.340)\end{array}$ & $\begin{array}{c}23.05 * * * \\
(2.995)\end{array}$ \\
\hline Constant & $\begin{array}{c}-190.5^{* * *} \\
(46.73)\end{array}$ & $\begin{array}{c}25.14 * * * \\
(2.853)\end{array}$ & $\begin{array}{c}-83.42 * * * \\
(26.01)\end{array}$ \\
\hline $\begin{array}{l}\text { Observations } \\
\text { Panels (countries) }\end{array}$ & $\begin{array}{l}80 \\
10\end{array}$ & $\begin{array}{l}70 \\
10\end{array}$ & $\begin{array}{l}70 \\
10\end{array}$ \\
\hline
\end{tabular}

Standard errors in parentheses; ${ }^{* * *} \mathrm{p}<0.01,{ }^{* *} \mathrm{p}<0.05, * \mathrm{p}<0.1$

(1) GLS estimator with panel-specific AR1 and cross-sectional dependent errors (2) \& (3) GLS estimator with panel-specific AR1 and heteroskedastic errors 
Table 4 Determinants of the corporate bond market

\begin{tabular}{|c|c|c|c|}
\hline VARIABLES & $\begin{array}{c}\text { (1) } \\
\text { corp_bond_gdp }\end{array}$ & $\begin{array}{c}\text { (2) } \\
\text { corp_bond_gdp }\end{array}$ & $\begin{array}{c}\text { (3) } \\
\text { corp_bond_gdp }\end{array}$ \\
\hline gdp_ppp & $\begin{array}{c}-2.742 * * * \\
(0.0607)\end{array}$ & & $\begin{array}{c}-2.237 * * * \\
(0.358)\end{array}$ \\
\hline gdp_capita_ppp & $\begin{array}{c}12.44 * * * \\
(0.212)\end{array}$ & & $\begin{array}{c}12.49 * * * \\
(1.068)\end{array}$ \\
\hline openness & $\begin{array}{c}-0.0304 * * * \\
(0.00131)\end{array}$ & & $\begin{array}{c}0.00135 \\
(0.00652)\end{array}$ \\
\hline i_spread & $\begin{array}{l}0.00425 \\
(0.0192)\end{array}$ & & $\begin{array}{c}-0.362 * * * \\
(0.0926)\end{array}$ \\
\hline bank_credit & $\begin{array}{c}0.0307 * * * \\
(0.00112)\end{array}$ & & $\begin{array}{c}0.0158 * \\
(0.00940)\end{array}$ \\
\hline xr_stability & $\begin{array}{c}1.840 * * * \\
(0.118)\end{array}$ & & $\begin{array}{c}2.935 * * * \\
(0.701)\end{array}$ \\
\hline corruption & & $\begin{array}{l}-0.466 \\
(0.661)\end{array}$ & $\begin{array}{c}-2.457 * * \\
(1.051)\end{array}$ \\
\hline law & & $\begin{array}{c}7.954 * * * \\
(0.433)\end{array}$ & $\begin{array}{l}0.0820 \\
(0.999)\end{array}$ \\
\hline regulatory & & $\begin{array}{c}4.844 * * * \\
(0.537)\end{array}$ & $\begin{array}{c}-2.440 * * \\
(1.225)\end{array}$ \\
\hline bank_concentration & & $\begin{array}{l}1.702 * \\
(0.978)\end{array}$ & $\begin{array}{c}1.401 \\
(1.186)\end{array}$ \\
\hline pension_dc & & $\begin{array}{c}2.871 \\
(2.871)\end{array}$ & $\begin{array}{c}1.570 \\
(1.344)\end{array}$ \\
\hline gov_commit & & $\begin{array}{c}19.78 * * * \\
(3.336)\end{array}$ & $\begin{array}{c}16.26^{* * *} \\
(1.312)\end{array}$ \\
\hline Constant & $\begin{array}{c}-23.99 * * * \\
(1.892)\end{array}$ & $\begin{array}{c}6.115 * * * \\
(0.714)\end{array}$ & $\begin{array}{c}-42.59 * * * \\
(10.02)\end{array}$ \\
\hline Observations & 110 & 80 & 80 \\
\hline Panels (countries) & 10 & 10 & 10 \\
\hline
\end{tabular}

Standard errors in parentheses; ${ }^{* * *} \mathrm{p}<0.01,{ }^{* *} \mathrm{p}<0.05,{ }^{*} \mathrm{p}<0.1$

(1), (2) and (3) GLS estimator with panel-specific AR1 and cross-sectional dependent errors 
Table 5 Testing hypothesis 2: externalities of the government bond market?

\begin{tabular}{|c|c|c|c|}
\hline Variables & $\begin{array}{c}\text { (1) } \\
\text { corp_bond_gdp }\end{array}$ & $\begin{array}{c}\text { (2) } \\
\text { corp_bond_gdp }\end{array}$ & $\begin{array}{c}\text { (3) } \\
\text { corp_bond_gdp }\end{array}$ \\
\hline gdp_ppp & $\begin{array}{c}-2.415^{* * *} \\
(0.141)\end{array}$ & & $\begin{array}{c}-1.622 * * \\
(0.691)\end{array}$ \\
\hline gdp_capita_ppp & $\begin{array}{c}12.33 * * * \\
(0.355)\end{array}$ & & $\begin{array}{c}14.04 * * * \\
(1.201)\end{array}$ \\
\hline openness & $\begin{array}{c}-0.0261 * * * \\
(0.00314)\end{array}$ & & $\begin{array}{l}-0.0181 \\
(0.0135)\end{array}$ \\
\hline i_spread & $\begin{array}{c}0.153 * * * \\
(0.0562)\end{array}$ & & $\begin{array}{l}-0.281 \\
(0.257)\end{array}$ \\
\hline bank_credit & $\begin{array}{c}0.0426^{* * *} \\
(0.00261)\end{array}$ & & $\begin{array}{c}0.0898 * * * \\
(0.0159)\end{array}$ \\
\hline xr_stability & $\begin{array}{c}0.315 \\
(0.313)\end{array}$ & & $\begin{array}{c}0.897 \\
(1.529)\end{array}$ \\
\hline gov_bond_gdp & $\begin{array}{c}-0.105 * * * \\
(0.0124)\end{array}$ & $\begin{array}{l}-0.00372 \\
(0.0146)\end{array}$ & $\begin{array}{c}-0.201 * * * \\
(0.0305)\end{array}$ \\
\hline corruption & & $\begin{array}{c}0.397 \\
(0.615)\end{array}$ & $\begin{array}{c}-4.600 * * \\
(1.860)\end{array}$ \\
\hline law & & $\begin{array}{c}5.310 * * * \\
(0.628)\end{array}$ & $\begin{array}{l}-1.256 \\
(1.972)\end{array}$ \\
\hline regulatory & & $\begin{array}{c}6.489 * * * \\
(0.832)\end{array}$ & $\begin{array}{c}2.457 \\
(1.878)\end{array}$ \\
\hline bank_concentration & & $\begin{array}{l}-0.667 \\
(1.251)\end{array}$ & $\begin{array}{l}-0.112 \\
(2.376)\end{array}$ \\
\hline pension_dc & & $\begin{array}{c}8.677 * * * \\
(1.999)\end{array}$ & $\begin{array}{l}4.859 * * \\
(2.091)\end{array}$ \\
\hline gov_commit & & $\begin{array}{c}10.42 * * * \\
(2.172)\end{array}$ & $\begin{array}{c}16.69 * * * \\
(1.475)\end{array}$ \\
\hline Constant & $\begin{array}{c}-30.21 * * * \\
(3.883)\end{array}$ & $\begin{array}{c}6.365 * * * \\
(1.315)\end{array}$ & $\begin{array}{c}-72.89 * * * \\
(15.78)\end{array}$ \\
\hline $\begin{array}{l}\text { Observations } \\
\text { Panels (countries) }\end{array}$ & $\begin{array}{c}110 \\
10\end{array}$ & $\begin{array}{l}80 \\
10\end{array}$ & $\begin{array}{l}80 \\
10\end{array}$ \\
\hline
\end{tabular}

Standard errors in parentheses; $* * * \mathrm{p}<0.01, * * \mathrm{p}<0.05, * \mathrm{p}<0.1$ (1), (2) and (3) GLS estimator with cross-sectional dependent errors 
Table 6 Testing hypothesis 3: GFC as a determinant of the corporate bond market?

\begin{tabular}{|c|c|c|c|}
\hline Variables & $\begin{array}{c}\text { (1) } \\
\text { corp_bond_gdp }\end{array}$ & $\begin{array}{c}\text { (2) } \\
\text { corp_bond_gdp } \\
\end{array}$ & $\begin{array}{c}\text { (3) } \\
\text { corp_bond_gdp }\end{array}$ \\
\hline gdp_ppp & $\begin{array}{c}-4.911 * * * \\
(0.345)\end{array}$ & & $\begin{array}{c}-1.835^{* * *} \\
(0.583)\end{array}$ \\
\hline gdp_capita_ppp & $\begin{array}{c}22.03 * * * \\
(0.398)\end{array}$ & & $\begin{array}{c}13.77 * * * \\
(1.453)\end{array}$ \\
\hline Openness & $\begin{array}{c}-0.0940 * * * \\
(0.00510)\end{array}$ & & $\begin{array}{c}-0.0520 * * * \\
(0.0102)\end{array}$ \\
\hline i_spread & $\begin{array}{c}-2.604 * * * \\
(0.121)\end{array}$ & & $\begin{array}{c}-0.621 * * * \\
(0.240)\end{array}$ \\
\hline bank_credit & $\begin{array}{l}-0.122 * * * \\
(0.00206)\end{array}$ & & $\begin{array}{c}-0.0694 * * * \\
(0.0136)\end{array}$ \\
\hline xr_stability & $\begin{array}{c}17.92 * * * \\
(0.900)\end{array}$ & & $\begin{array}{c}11.70 * * * \\
(2.129)\end{array}$ \\
\hline Gfc & $\begin{array}{c}2.023 * * * \\
(0.332)\end{array}$ & $\begin{array}{c}2.449 * * * \\
(0.921)\end{array}$ & $\begin{array}{c}2.423 * * \\
(0.986)\end{array}$ \\
\hline Corruption & & $\begin{array}{c}-15.20 * * * \\
(1.875)\end{array}$ & $\begin{array}{c}-8.732 * * * \\
(2.250)\end{array}$ \\
\hline Law & & $\begin{array}{c}18.24 * * * \\
(1.131)\end{array}$ & $\begin{array}{c}8.583 * * * \\
(2.309)\end{array}$ \\
\hline Regulatory & & $\begin{array}{c}11.31 * * * \\
(1.552)\end{array}$ & $\begin{array}{l}4.485^{*} \\
(2.531)\end{array}$ \\
\hline bank_concentration & & $\begin{array}{c}-9.771 * * * \\
(1.610)\end{array}$ & $\begin{array}{c}-10.85 * * * \\
(2.207)\end{array}$ \\
\hline pension_dc & & $\begin{array}{c}4.120 * * * \\
(0.948)\end{array}$ & $\begin{array}{c}4.674 * * * \\
(1.144)\end{array}$ \\
\hline gov_commit & & $\begin{array}{c}15.11^{* * * *} \\
(0.967)\end{array}$ & $\begin{array}{c}7.842^{* * * *} \\
(1.863)\end{array}$ \\
\hline Constant & $\begin{array}{c}-22.30 * * \\
(8.674)\end{array}$ & $\begin{array}{c}9.964 * * * \\
(1.333)\end{array}$ & $\begin{array}{c}-46.99 * * * \\
(14.11)\end{array}$ \\
\hline Observations & 110 & 90 & 90 \\
\hline Panels (countries) & 10 & 10 & 10 \\
\hline
\end{tabular}

Standard errors in parentheses; $* * * \mathrm{p}<0.01, * * \mathrm{p}<0.05, * \mathrm{p}<0.1$

(1), (2) \& (3) GLS estimator with cross-sectional dependent errors 


\section{REFERENCES}

ADB Asian Bonds Online. "Asia Bond Monitor - November 2011.” 2011, http://asianbondsonline.adb.org/documents/abm_nov_2011.pdf, accessed May 2012

Agénor, Pierre-Richard, and Peter K. Montiel. Development Macroeconomics. Third Edition. New Jersey: Princeton University Press, 2008

Aizenman, Joshua, and Reuven Glick. "Sterilization, Monetary Policy, and Global Financial Integration." In Review of International Economics, 17/4, 2009, pp. 777-801

Aizenman, Joshua, Menzie D. Chinn, and Hiro Ito. "Assessing the Emerging Global Financial Architecture: Measuring the Trilemma's Configurations over Time.” NBER Working Paper No. 14533, 2008; updated 2010, Version of Indexes, Indexes Data, http://web.pdx.edu/ ito/trilemma_indexes_update2010.xls, accessed June 2012

Alexandros, Gabrielsen, Marzo Massimiliano, and Zagaglia Paolo. "Measuring Market Liquidity: An Introductory Survey.” MPRA Paper No. 35829, 2011

Ananchotikul, Sudarat, and Barry Eichengreen. "Corporate Governance Reform in Emerging Markets: How Much, Why, and with What Effects?" In Journal of the Japanese and International Economies, 23/2, 2009, pp. 149-176

AsianBondsOnline. "Bond Market Liquidity Survey.” 2011, http://asianbondsonline.adb.org/ surveys/liquidity_survey_2011/abo_2011_bond_market_liquidity_survey.pdf, accessed April 2012

AsianBondsOnline. "Asian Bonds Online Database.” 2012, http://asianbondsonline.adb.org/, accessed June 2012

Bae, Byung-Yoon, and Dong-Heon Kim. "Global and Regional Yield Curve Dynamics and Interactions: The Case of Some Asian Countries." In International Economic Journal, 25/4, 2011, pp. 717-738

Baker, Kenneth H. "Trading Location and Liquidity: An Analysis of U.S. Dealer and Agency Markets for Common Stocks.” In Financial Markets Institutions and Instruments, 5/4, 1996, pp. 1-51

Barth, James R., Donald McCarthy, Triphon Phumiwasana, and Glenn Yago. "Opportunities and Challenges in Asian Bond Markets." In Asia's Debt Capital Markets: Prospects and Strategies for Development, edited by Douglas Arner, Jae-Ha Park, Paul Lejot, and Qiao Liu. New York: Springer, 2006

Beck, Nathaniel, and Jonathan N. Katz. "What to Do (and Not to Do) with Time-Series CrossSection Data." In The American Political Science Review, 89/3, 1995, pp. 634-647

Beck, Thorsten, Asli Demirgüç-Kunt, and Ross Levine. "Financial Institutions and Markets across Countries and over Time: The Updated Financial Development and Structure Database." In The World Bank Economic Review, 24/1, 2010, pp. 77-92

Bhattacharyay, Biswa Nath. "Bond Market Development in Asia: An Empirical Analysis of Major Determinants." ADBI Working Paper Series, no. 300, 2011

Black, Susan, and Anella Munro. "Why Issue Bonds Offshore?" BIS Papers No 52. Bank for International Settlements, 2010

Bolton, Patrick, and Xavier Freixas. "Equity, Bonds, and Bank Debt: Capital Structure and Financial Market Equilibrium under Asymmetric Information.” In Journal of Political Economy, 108/2, 2000

Borensztein, Eduardo, and Prakash Loungani. "Asian Financial Integration: Trends and Interruptions." In Costs and Benefits of Economic Integration in Asia, edited by Robert J. Barro. Oxford: Oxford University Press, 2011 
Brunner, Karl, and Allan H. Meltzer. "Friedmans Monetary Theory.” In Journal of Political Economy, 80/2, 1972, pp. 837-851

Burger, John D., and Francis E. Warnock. "Local Currency Bond Markets.” IMF Staff Papers 53, 2006, pp. 133-146

Byun, Hae-Young. "The Cost of Debt Capital and Corporate Governance Practices." In AsiaPacific Journal of Financial Studies, 36/5, 2007, pp. 765-806

Calvi, Rossella. "Assessing Financial Integration: A Comparison between Europe and East Asia." European Commission Economic Papers, no. 423, 2010

Chan, Eric, Michael Chui, Frank Packer, and Eli Remolona. "Local Currency Bond Markets and the Asian Bond Fund 2 Initiative." In "Weathering Financial Crises: Bond Markets in Asia and the Pacific.” BIS Papers No 63. Bank for International Settlements and Bank of Japan, 2012

De Hoyos, Rafael E., and Vasilis Sarafidis. "Testing for Cross-Sectional Dependence in PanelData Models.” In The Stata Journal, 6/4, 2006, pp. 482-496

Dickie, Paul, and Emma Xiaoqin Fan. "Banks and Corporate Debt Market Development." ERD Working Papers No 67, 2005

Drukker, David M. "Testing for Serial Correlation in Linear Panel-data Models." In The Stata Journal, 3/2, 2003, pp. 168-177

ECB. "Yield Curve - Technical Notes." 2012, http://www.ecb.int/stats/money/yc/html/technical_notes.pdf, accessed Febuary 2012

Eichengreen, Barry, and Pipat Luengnaruemitchai. "Why Doesn't Asia have Bigger Bond Markets?" In "Asian Bond Markets: Issues and Prospects.” BIS Papers No 30. Bank for International Settlements, 2006

Emmers, Ralf, and John Ravenhill. "The Asian and Global Financial Crises: Consequences for East Asian Regionalism.” RSIS Working Paper No. 208, 2010

Estrada, Gemma, Donghyun Park, and Arief Ramayandi. "Financial Development and Economic Growth in Developing Asia." ADB Economics Working Paper Series No. 233, 2010

Fase, Martin M. G., and R. C. N. Abma. "Financial Environment and Economic Growth in Selected Asian Countries.” In Journal of Asian Economics, 14, 2003, pp. 11-21

Felman, Joshua, Simon Gray, Mangal Goswami, Andreas Jobst, Mahmood Pradhan, Shanaka Peiris, and Dulani Seneviratne. "ASEAN-5 Bond Market Development: Where Does It Stand? Where is It Going?" IMF Working Paper WP/11/137, 2011

Fink, Gerhard, Peter Haiss, and Sirma Hristoforova. "Bond Markets and Economic Growth." IEF Working Paper No. 49, 2003

Fink, Gerhard, Peter Haiss, and Goran Vuksić. "Contribution of Financial Market Segments at Different Stages of Development: Transition, Cohesion and Mature Economies Compared." In Journal of Financial Stability 5, 2009, pp. 431-455

Fry, Maxwell J. Emancipating the Banking System and Developing Markets for Government Debt. London: Routledge, 1997

Fung, Michael K. "Financial Development and Economic Growth: Convergence or Divergence?" In Journal of International Money and Finance, 28, 2009, pp. 56-67

Greenspan, Alan. “Do Efficient Financial Markets Mitigate Financial Crises?” October 19, 1999, Speech before the 1999 Financial Markets Conference of the Federal Reserve Bank of Atlanta, Atlanta, http://www.federalreserve.gov/boarddocs/speeches/1999/19991019.htm, accessed February 2012

Greenwood, John. "The Costs and Implications of PBC Sterilization.” In Cato Journal, 28/2, 2008 Habibullah, Muzafar Shah, and Yoke-Kee Eng. "Does Financial Development Cause Economic Growth? A Panel Data Dynamic Analysis for the Asian Developing Countries." In Journal of the Asia Pacific Economy, 11/4, 2006, pp. 377-393 
IMF. International Financial Statistics (IFS) Database, accessed June 2012

Ismail, Izlin, and G. Sivalingam. "The Asian Bond Fund: A Case Study of Successful Economic and Financial Cooperation in Asia." In Investment Management and Financial Innovations, 3, 2006, pp. 23-34

Johansson, Anders C. "Interdependencies among Asian Bond Markets." In Journal of Asian Economics, 19/19, 2008, pp. 101-116

Kaufmann, Daniel, Aart Kraay, and Massimo Mastruzzi. "The Worldwide Governance Indicators: A Summary of Methodology, Data and Analytical Issues." World Bank Policy Research Working Paper No. 5430, 2010; 2011 Update of Indicators. http://info.worldbank.org/ governance/wgi/pdf/wgidataset.xlsx accessed June 2012.

Keele, Luke J., and Nathan J. Kelly. "Dynamic Models for Dynamic Theories: The Ins and Outs of Lagged Dependent Variables." In Political Analysis, 14, 2006, pp. 186-205

Khalid, Ahmed M., and Gulasekaran Rajaguru. "Market Development for Fixed Income Securities: The Role of Socio-Economic and Institutional Factors." Bond University Working Paper No. 42, 2010

La Porta, Rafael, Florencio Lopez-de-Silanes, Andrei Shleifer, and Robert W. Vishny. "Law and Finance." In Journal of Political Economy, 106/6, 1998, pp. 1113-1155

Levine, Ross. "Financial Development and Economic Growth: Views and Agenda." In Journal of Economic Literature, 35/2, 1997, pp. 699-726

Lin, Chen, Yue Ma, Paul Malatesta, and Yuhai Xuan. "Corporate Ownership Structure and the Choice between Bank Debt and Public Debt.” SSRN Working Paper Series, 2012

Löffler, Axel, Gunther Schnabl, and Franziska Schobert. "Limits of Monetary Policy Autonomy by East Asian Debtor Central Banks." CESifo Working Paper No. 3742, 2012

Lucas, Robert E. "On the Mechanics of Economic Development." In Journal of Monetary Economics, 22, 1988, pp. 3-42

McCauley, Robert, and Eli Remolona. "Size and Liquidity of Government Bond Markets." In BIS Quarterly Review, November 2000, pp. 52-60

Mehl, Arnaud. "The Yield-Curve as a Predictor and Emerging Economies." ECB Working Paper Series No. 691, 2006

Mohanty, Madhusudan, and Philip Turner. "Foreign Exchange Reserve Accumulation in Emerging Markets: What are the Domestic Implications.” In BIS Quarterly Review, September 2006

Nyawata, Obert. "Treasury Bills and/or Central Bank Bills for Absorbing Surplus Liquidity: The Main Considerations.” IMF Working Paper WP/12/40, 2012

OECD. "Pensions at a Glance Asia/Pacific 2011." OECD Publishing, 2012, http://dx.doi.org/10.1787/9789264107007-en, accessed May 2012.

Park, Yung-Chul, and Charels Wyplosz. Monetary and Financial Integration in East Asia: The Relevance of the European Experience. Oxford: Oxford University Press, 2010

Peiris, Shanaka. J. "Foreign Participation in Emerging Markets' Local Currency Bond Markets." IMF Working Paper WP/10/88, 2010

Rajan, Raghuram G., and Luigi Zingales. "The Great Reversals: The Politics of Financial Development in the Twentieth Century." In Journal of Financial Economics, 69, 2003, pp. 5-50

Sarr, Abdourahmane, and Tonny Lybek. "Measuring Liquidity in Financial Markets." IMF Working Paper WP/02/232, 2002

Schumpeter, Joseph Alois. Theorie der wirtschaftlichen Entwicklung. Duncker \& Humbolt, 1993 [1911]

Shim, Illhyock. "Development of Asia-Pacific Corporate Bond and Securitisation Markets." In "Weathering Financial Crises: Bond Markets in Asia and the Pacific." BIS Papers No 63. Bank for International Settlements and Bank of Japan, 2012 
Spratt, Stephen. Development Finance: Debates, Dogmas and New Directions. Abingdon, Oxon: Routledge, 2009

Turner, Philip. "Weathering Financial Crises: Domestic Bond Markets in EMEs.” In "Weathering Financial Crises: Bond Markets in Asia and the Pacific." BIS Papers No 63. Bank for International Settlements and Bank of Japan, 2012

Wiggins, Vince, and Brian Poi. "Testing for Panel-level Heteroskedasticity and Autocorrelation." 2003, http://www.stata.com/support/faqs/stat/panel.html, 2003, accessed June 2012

Wooldridge, Jeffrey. M. Econometric Analysis of Cross Section and Panel Data. Cambridge MA; London: The MIT Press, 2002

World Bank. Developing Government Bond Markets: A Handbook. Washington DC: The International Bank for Reconstruction, 2001

World Bank. "World Development Indicators (WDI) and Global Development Finance (GDF) Database." 2012, http://databank.worldbank.org/databank/download/WDIandGDF_excel.zip, accessed June 2012

Yu, Ip-Wing, Laurence Fung, and Chi-Sang. Tam. "Assessing Bond Market Integration in Asia." Hong Kong Monetary Authority Working Paper, no.10, 2007a

Yu, Ip-Wing, Laurence Fung, and Chi-Sang Tam. "Assessing Financial Market Integration in Asia: Equity Markets.” Hong Kong Monetary Authority Working Paper, no.04, 2007b 